\title{
Anticarcinogenic effect of alpha-lipoic acid and Jatropha gossypifolia leaves against cypermethrin-induced genotoxicity in rats
}

\begin{tabular}{|c|c|}
\hline \multicolumn{2}{|c|}{$\begin{array}{l}\text { Authors: } \\
\text { Opeyemi O. Faokunla }{ }^{1} \text { (1) } \\
\text { Oluseyi A. Akinloye }^{2} \\
\text { Regina N. Ugbaja }{ }^{2} \text { @ } \\
\text { Abideen I. Adeogun }{ }^{3} \text { @ }\end{array}$} \\
\hline \multicolumn{2}{|c|}{$\begin{array}{l}\text { Affiliations: } \\
\text { 'Department of Biological } \\
\text { Sciences, College of Natural } \\
\text { and Applied Sciences, Wesley } \\
\text { University, Nigeria }\end{array}$} \\
\hline \multicolumn{2}{|c|}{$\begin{array}{l}{ }^{2} \text { Department of Biochemistry, } \\
\text { College of Biological Sciences, } \\
\text { Federal University of } \\
\text { Agriculture, Nigeria }\end{array}$} \\
\hline \multicolumn{2}{|c|}{$\begin{array}{l}{ }^{3} \text { Department of Chemistry, } \\
\text { College of Biological Sciences, } \\
\text { Federal University of } \\
\text { Agriculture, Nigeria }\end{array}$} \\
\hline \multicolumn{2}{|c|}{$\begin{array}{l}\text { Corresponding author: } \\
\text { Opeyemi Faokunla, } \\
\text { arkofgod0506@yahoo.com }\end{array}$} \\
\hline \multicolumn{2}{|c|}{$\begin{array}{l}\text { Dates: } \\
\text { Received: } 16 \text { Nov. } 2017 \\
\text { Accepted: } 30 \text { Dec. } 2017 \\
\text { Published: } 26 \text { Feb. } 2018\end{array}$} \\
\hline \multicolumn{2}{|c|}{$\begin{array}{l}\text { How to cite this article: } \\
\text { Faokunla, O.O., Akinloye, } \\
\text { O.A., Ugbaja, R.N. \& } \\
\text { Adeogun, A.I., 2018, } \\
\text { 'Anticarcinogenic effect of } \\
\text { alpha-lipoic acid and } \\
\text { Jatropha gossypifolia leaves } \\
\text { against cypermethrin- } \\
\text { induced genotoxicity in rats', } \\
\text { Journal of Medicinal Plants } \\
\text { For Economic Development } \\
\text { 2(1), a45. https://doi. } \\
\text { org/10.4102/jomped.v2i1.45 }\end{array}$} \\
\hline \multicolumn{2}{|c|}{$\begin{array}{l}\text { Copyright: } \\
\text { (c) 2018. The Authors. } \\
\text { Licensee: AOSIS. This work } \\
\text { is licensed under the } \\
\text { Creative Commons } \\
\text { Attribution License. }\end{array}$} \\
\hline \multirow[b]{2}{*}{ Read online: } & \\
\hline & $\begin{array}{l}\text { Scan this QR } \\
\text { code with your } \\
\text { smart phone or } \\
\text { mobile device } \\
\text { to read online. }\end{array}$ \\
\hline
\end{tabular}

Background: Cypermethrin (Сур), a synthetic pyrethroid developed for agricultural and public health applications, has become harmful to the environment and mammalian life owing to indiscriminate use.

Aim: This study aimed to investigate the protective effect of the methanolic extract of Jatropha gossypifolia leaves against Cyp-induced genotoxicity in rats using alpha-lipoic acid ( $\alpha$-LA) as standard drug.

Method: Fifty-six male Wistar rats, assigned to eight groups of seven animals each, were treated orally for 28 days as follows - Group 1: only corn oil (Control); Group 2: $20 \mathrm{mg} / \mathrm{kg}$ body weight (b.wt) of Cyp; Groups 3, 4 and 5: Cyp $+50 \mathrm{mg} / \mathrm{kg}$ b.wt of J. gossypifolia, Cyp + $100 \mathrm{mg} / \mathrm{kg}$ b.wt of J. gossypifolia and Cyp $+50 \mathrm{mg} / \mathrm{kg}$ b.wt of $\alpha$-LA, respectively; Groups 6, 7 and 8: J. gossypifolia (50 mg/kg b.wt), J. gossypifolia (100 mg/kg b.wt) and $\alpha$-LA (50 mg/kg b.wt), respectively. The P53 was assayed for using the plasma, while the micronucleus assay was carried out on the bone marrow.

Results: Results showed that exposure to Cyp significantly increased the number of micronucleated polychromatic erythrocytes $(86.70 \%)$ as well as p53 concentration in both the liver and plasma (200.00\% and $125.53 \%)$ compared to the control. Co-administration with methanolic extract of $J$. gossypifolia leaves significantly reversed these alterations in a dosedependent manner.

Conclusion: The methanolic extract of J. gossypifolia leaves has the potential to ameliorate Cyp-induced genotoxicity in rats, and also, the toxicological evaluations of the plant extract and $\alpha$-LA showed that it is relatively safe for use at the doses investigated.

\section{Introduction}

There has been a great improvement in the economic and social well-being of both the developing and the developed world arising from application of pesticides, improved food production and preservation for the growing world population (Ojezele \& Abatan 2009). However, indiscriminate use of pesticides has led to varying degree of deleterious effects in non-target organisms such as fishes, birds and mammals, especially humans (Ecobichon 1996). Blood disorders, brain and nerve damage, paralysis, emphysema, asthma, cancer, birth defects and infertility have reportedly been linked to low residual amount of pesticides (Gold et al. 2001). Being a reactive compound, pesticide tends to form covalent bonds with various nucleophilic centres of cellular biomolecules such as DNA (Poletta et al. 2009), resulting in cancer and other chronic diseases (Meinert et al. 2000).

Synthetic pyrethroids were therefore produced with the aim of minimising mammalian toxicity, insect resistance and persistence posed by organophosphorus, carbamates and organochlorine pesticides to the ecosystem (Osweiler 1996). Contrary to the opinion that they are safe, recent literature has shown that synthetic pyrethroids pose serious health challenges, with the Cancer Assessment Review Committee for pyrethrins attributing the increased incidences of thyroid and liver tumours to pyrethrum treatment and classified pyrethrins as 'likely to be a human carcinogen by the oral route' (Giri et al. 2003). Cypermethrin (Cyp), a synthetic pyrethroid belonging to the $\alpha$-cyano group, has been associated with adverse effects on non-target organisms because of continuous and excessive exposure (Cuthbertson \& Murchie 2010). Cypermethrin has been shown to induce genotoxicity in the bone marrow of experimental animals (Assayed, Khalaf \& Salem 2010; Okonko, Ikpeme \& Udensi 2016). 
In recent times, plants have been investigated for their medicinal potentials because of their antioxidant properties, reduced side effects and economic viability (Auudy et al. 2003). One of such is Jatropha gossypifolia, a medicinal plant commonly used in the southern part of Nigeria to treat various ailments such as malaria, typhoid, thrush, eczema and stomach-ache (Balee 1994). Scientific report showed that extracts of the plant exhibit pharmacological activities: anti-inflammatory (Yerramsetty et al. 2013), analgesic (Panda et al. 2009), antimicrobial (Seth \& Sarin 2010), antipyretic, purgative (Murugalakshmi et al. 2014), anticancer, hepatoprotective and anti-diarrhoeal (Apurba et al. 2013). These pharmacological effects could be attributed to the phytoconstituents (hispogenin, ricinine, lutein, lycopene, resveratrol, apigenin and isovitexin) isolated from the leaves of this plant (Faokunla et al. 2017).

Alpha-lipoic acid ( $\alpha$-LA) is a vitamin-like chemical antioxidant discovered in 1951 (Rosenberg \& Culik 1959). However, its anti-toxin effect cannot be linked to its action as a substrate for pyruvate dehydrogenase nor its antioxidant effects (Raddatz \& Bisswanger 1997). Alphalipoic acid has been investigated as a possible adjunctive treatment for various conditions, including diabetes mellitus and associated complications (Packer, Kraemer \& Rimbach 2001; Ziegler, Ametov \& Barinov 2006), cancer (Wenzel, Nickel \& Daniel 2005), ischaemia and reperfusion injury (Sehirli, Sener \& Centinel 2008), Amanita mushroom poisoning (Packer, Witt \& Tritschler 1995), Alzheimer's disease and related dementias (Holmquist, Stuchbury \& Berbaum 2007), heavy metal toxicities (Grunert 1960), and HIV and AIDS (Baur, Harrer \& Peukert 1991). Research has further elucidated that phase II induction in the lungs could protect against the carcinogenic effects of cigarette smoke (Singh et al. 2009). Other antioxidants perform more effectively in water (vitamin C) or fatty tissues (vitamin E), but $\alpha$-LA is both water and fat soluble, with evidence suggesting its ability to regenerate other antioxidants (Packer et al. 1995). Alpha-lipoic acid is a special antioxidant because of its versatility at deactivating an unusually wide array of cell-damaging free radicals in many different parts of cells and tissues, including the mitochondria and the genetic material (DNA) (Bilska et al. 2008).

Acentric chromosomal fragments become micronuclei when lost during cell division (Renner 1990). Although these micronuclei do not provide the cytogeneticist with important details of the aberration types from which they arose, they are much more easily and rapidly quantified and so provide a simple means of detecting the occurrence of chromosomal damage (Renner 1990). No agents have yet been found that can cause aberrations of any kind without causing those kinds that have associated acentric fragments. Micronuclei should thus be a reliable index of chromosome damage (Chung, Cheon \& Ku 2011). They were used once as an experimental tool in plants and noted occasionally in other circumstances, but were not used as an assay until independently proposed by Schmid and co-workers (Matter \& Schmid 1971) and Heddle (1973). The cell type proposed by Schmid was the polychromatic erythrocyte (PCE). This cell, although not itself a dividing cell, is the immediate product of a series of cell divisions. The success of this assay can be judged by the fact that it has largely replaced traditional metaphase analysis in the screening of chemicals for their ability to produce chromosomal damage in vivo.

Cypermethrin-induced genotoxicity can be evaluated using micronucleus test and tumour suppressor protein, p53. These assays are widely used because of their rapid and high sensitivity in the detection of mutagenicity and genotoxicity of chemicals and xenobiotics (Ali et al. 2008). The bone marrow micronucleus test is therefore a short-term technique for elucidating the mechanism and identifying the clastogenic and anti-clastogenic activity of a substance (Renner 1990). Cypermethrin has been reported to be genotoxic (Okonko et al. 2016), but to the best of our knowledge, the alleviation of this toxicity using $\alpha$-LA and J. gossypifolia leaf extract has not been reported. Hence, this study is aimed at investigating the anticarcinogenic effect of $\alpha$-LA and J. gossypifolia leaves in rats orally exposed to Cyp.

\section{Materials and methods}

\section{Animals}

Fifty-six adult male Wistar rats were purchased from the animal house of the Department of Veterinary Medicine, University of Ibadan, Nigeria, and housed at the animal house of the Department of Biochemistry, Federal University of Agriculture, Abeokuta, Nigeria. The animals were acclimatised for a period of two weeks under standard environmental conditions, with an approximately $12 \mathrm{~h}$ light and dark cycle, and were fed a standard laboratory diet and water ad libitum. After two weeks of acclimatisation, the animals were subjected to various treatments for a period of four weeks. The animals used in this study were maintained in accordance with the principles and guidelines of the Canadian Council on Animal Care as outlined in 'Guide for the Care and Use of Laboratory Animals' (Canadian Council on Animal Care 1993).

\section{Methanolic extraction of Jatropha gossypifolia}

Fresh leaves of J. gossypifolia were plucked from Bashiri area of Ado-Ekiti and authenticated at the Plant Science Department of the Ekiti State University, Ado-Ekiti, by plant taxonomist, Mr F. O. Omotayo, with an electronic herbarium number UHAE163. The leaves of the plant were rinsed with clean water to avoid any form of contamination, then air-dried under shade for about two weeks and mechanically pulverised using an electric blender (QASA, QBL-15L40, Taiwan) into a fine texture prior to extraction. About $500 \mathrm{~g}$ of the powdered form was soaked in $3.3 \mathrm{~L}$ of methanol for $72 \mathrm{~h}$. The solvent was decanted and filtered using Whatman (no 1) filter paper. The extract was then concentrated with the aid of a rotary evaporator at $40^{\circ} \mathrm{C}$. The percentage yield of the 
methanolic extract was $9.8 \% \mathrm{w} / \mathrm{w}$. The concentrated methanolic extract obtained was stored at $-4^{\circ} \mathrm{C}$ until use.

\section{Alpha-lipoic acid}

Pure $\alpha$-LA was obtained from Hangzhou Zhenghan Biological Technology Co., Limited, China (Batch No: 10005728).

\section{Experimental design}

The animals were divided into eight groups of seven animals, each based on their weight ranges (120-150 g) as shown in Table 1. Administration was carried out orally using orogastric cannula for a period of 28 days. Cypermethrin, J. gossypifolia methanolic leaf extract (JGLE) and $\alpha$-LA were all dissolved in corn oil and administered to the rats once daily all through the duration of the experiment.

\section{Blood collection}

The blood samples obtained through ocular puncture using heparinised capillary tubes were collected into labelled heparinised bottles and centrifuged at $4000 \mathrm{rpm}$ for $10 \mathrm{~min}$. This was to separate the whole blood into plasma and erythrocytes. The plasma was carefully removed using a needle and syringe and stored in the freezer at $-4^{\circ} \mathrm{C}$ for further analysis at the Department of Biochemistry, Federal University of Agriculture, Abeokuta.

\section{Micronucleus assay}

The methods proposed by Schmid and Heddle were employed in this assay (Heddle 1973; Matter \& Schmid 1971). The principle of the micronucleus assay is based on the fact that PCE cells have a staining property that is different from the normal mature erythrocyte (normocyte). The polychromatic staining property results from the presence of ribosomal RNA $24 \mathrm{~h}$ prior to the formation of the cell. As PCEs develop into mature erythrocytes, they lose the ribosomal RNA and the staining property. In mammals, mature erythrocytes expel their nuclei 8-12 h after the last mitosis preceding the formation of an erythrocyte. The micronuclei for some reason, are not expelled completely. Micronuclei are not normally found in the circulating erythrocytes in blood because they are filtered out by the spleen (Schalm 1970).

TABLE 1: Drug administration

\begin{tabular}{ll}
\hline Groups & Treatment \\
\hline 1 & Control (corn oil) \\
2 & Cypermethrin only $20 \mathrm{mg} / \mathrm{kg}$ \\
3 & Cyp $20 \mathrm{mg} / \mathrm{kg}+$ JGLE $50 \mathrm{mg} / \mathrm{kg}$ \\
4 & Cyp $20 \mathrm{mg} / \mathrm{kg}+$ JGLE $100 \mathrm{mg} / \mathrm{kg}$ \\
5 & Cyp $20 \mathrm{mg} / \mathrm{kg}+\alpha$-LA $50 \mathrm{mg} / \mathrm{kg}$ \\
6 & JGLE $50 \mathrm{mg} / \mathrm{kg}$ \\
7 & JGLE $100 \mathrm{mg} / \mathrm{kg}$ \\
8 & $\alpha$-LA $50 \mathrm{mg} / \mathrm{kg}$ \\
\hline Cyp, cypermethrin; JGLE, Jatropha gossypifolia methanolic leaf extract; $\alpha$-LA, alpha-lipoic \\
acid.
\end{tabular}

After sacrificing the animals, the two femurs were excised from the hip joint. A pair of scissors was used to make a small opening in the iliac end of each of the rat femur, and the needle of a syringe was used to aspirate the bone marrow at the epiphyseal end. This needle was slowly pushed up into the canal; this caused the marrow to exude out at iliac end. The exuded marrow was then placed onto a slide to which a drop of bovine serum albumin from a pipette was added. This was mixed homogenously with the edge of a clean slide and smeared for staining procedure.

The staining procedure commenced with the dipping of the slide into absolute methanol for $5 \mathrm{~min}$ to fix the cells and air-dried afterwards. The slide was immediately stained with $0.4 \%$ May-Grünwald stains 1 and 2, in sequence, and then air-dried. The slide was further dipped in 5\% Giemsa stain for $30 \mathrm{~min}$, rinsed in phosphate buffer for $30 \mathrm{~s}$ and also rinsed in distilled water. The slide was further air-dried and finally fixed in xylene for $20 \mathrm{~min}$, after which it was finally air-dried and then mounted in a DPX mountant with cover slips. Cells containing the micronuclei were then viewed and counted under the microscope.

\section{p53 enzyme-linked immunosorbent assay}

The principle employed by the tumour protein (TP53) enzyme-linked immunosorbent assay (ELISA) kit (Cat. No: CK-E30334) uses a double antibody sandwich ELISA to assay the level of rat p53/tumour protein (p53/Tp53) in samples.

To the wells containing the blank, standard and the prepared samples, already labelled antibody was added and incubated for $60 \mathrm{~min}$ at $37^{\circ} \mathrm{C}$. These were then washed five times, after which Chromogen solutions A and B were added, mixed and incubated for $10 \mathrm{~min}$ at $37^{\circ} \mathrm{C}$ in the dark. A blue colouration was obtained after incubation. The reaction was terminated by the addition of the stop solution which was indicated by an immediate colour change from blue to yellow. The optical density (OD) was then measured at $450 \mathrm{~nm}$ wavelength within $15 \mathrm{~min}$ of adding the stop solution.

\section{Statistical analysis}

All values are expressed as means \pm standard deviations. Data were analysed by one-way ANOVA, and significant differences between groups were determined by Duncan's multiple range test and least significant difference. Statistical analyses were conducted using SPSS, the statistical package for Windows, version 17.0. The acceptable level of significance was $p<0.05$.

\section{Ethical considerations}

All chemicals used were of analytical grade. The animals used for this research were of good health condition and were sacrificed humanely, under anaesthetic conditions. 


\section{Results}

Higher mean numbers of micronucleated polychromatic erythrocytes (mPCEs) were seen in this study in the group exposed to Cyp, which was found to be significant compared to the control. Supplementation with the methanolic leaf extract of J. gossypifolia at the two doses under study significantly reduced the frequency of mPCEs in a dosedependent manner, whereas $\alpha$-LA supplementation showed more potency at curbing the Cyp-induced clastogenicity. Also from this study, oral administration of the methanolic leaf extract of $J$. gossypifolia and $\alpha$-LA alone showed no significant difference compared to control (Figure 1).

Cypermethrin caused a significant increase in the concentration of liver and plasma p53 compared to the control (Figure 2). This was significantly lowered by the co-administration of the extract of J. gossypifolia and $\alpha$-LA at the doses under investigation when compared to the group administered with Cyp alone. Also, in comparison with the control group, the groups given $\alpha$-LA and the plant extract alone showed no significant relationship.

\section{Discussion}

This study was carried out with the aim of investigating the possible anti-genotoxic effect of the extract of J. gossypifolia leaves. The result shown in Figure 1 above is in agreement with the findings of Ganapathy and Shanmugam (2010) in which the administration of 7,12-dimethylbenz[a]anthracene (DMBA) significantly increased the frequency of mPCEs in the bone marrow and consequent oral supplementation with berberine markedly reduced the frequency of mPCEs. Hammam and El-Khatib (2004) also studied the genotoxic effect of diazinon on male rats using dipping and spraying method. The data showed that exposure to diazinon increases the frequency of chromosomal aberration and induction of micronuclei in the bone marrow cells of rats when compared to the negative control and the other treated group. Similarly,

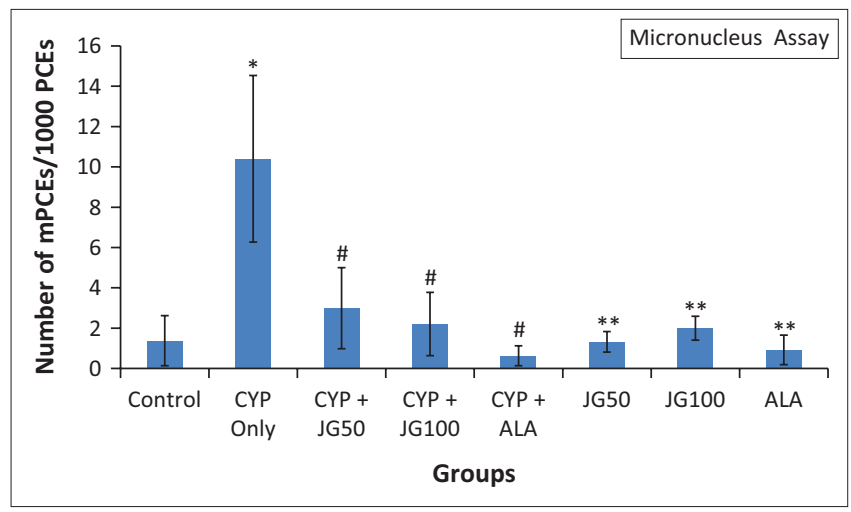

The bars represent mean $\pm \mathrm{SD}(n=5)$; *, values are significant at $p<0.05$ when compared to the control group; \#, values are significant at $p<0.05$ when compared to Cyp-only group **, values are not significant at $p<0.05$ when compared to the control group.

mPCEs, micronucleated polychromatic erythrocytes; PCEs, polychromatic erythrocytes; Cyp, cypermethrin.

FIGURE 1: Effect of crude methanolic leaves extract of Jatropha gossypifolia (J. gossypifolia $50 \mathrm{mg}$ and J. gossypifolia $100 \mathrm{mg}$ ) and alpha-lipoic acid ( $\alpha$-LA $50 \mathrm{mg}$ ) on the mean number of micronucleated polychromatic erythrocytes in rats pretreated with cypermethrin. it was found by Yekeen and Adeboye (2013) that Cyp and alphamethrin were able to induce a clastogenic effect in Allium cepa root. It was also confirmed by Navayath and Thiyagarajan (2013) that Cyp-induced clastogenicity and treatment with $10 \%$ gluten-free aqueous extract of fenugreek, an antioxidant, showed significant reduction in DNA damage. The result also suggests that the oral administration of $\alpha$-LA and the methanolic leaf extract of J. gossypifolia at $50 \mathrm{mg} / \mathrm{kg}$ and $100 \mathrm{mg} / \mathrm{kg}$ body weight showed no genotoxic effect when compared to the control.

In addition, this study also revealed that Cyp-induction in rats increased the expression of plasma and liver p53 remarkedly at the mRNA level (Figure 2). There were significant increase in plasma and liver p53 concentrations in the groups that took Cyp only, which could be attributed to the activation of the protein activity. This could also be as a result of the activation of apoptosis-related genes (such as p53, caspase 3 and 9) by the Cyp administration. p53 is activated when DNA damage occurs or cells are stressed, resulting in its translocation to the nucleus, where it can induce pro-apoptotic gene expression on the mitochondrial membrane and activate the effector caspases and ultimately accelerate cell death (Levine 1997; Sheikh \& Fornace 2000). However, after treatment with the methanolic leaf extract of $J$. gossypifolia and $\alpha$-LA, there was a decrease in the concentration of p53 level in groups co-administered with the plant extract and $\alpha$-LA when compared with the group administered with Cyp alone.

\section{Conclusion}

Having confirmed the genotoxicity of Cyp in non-target organisms, this study has shown that co-administration with the methanolic leaf extract of J. gossypifolia and $\alpha$-LA effectively ameliorated Cyp-induced clastogenicity. In addition, both the extract and $\alpha$-LA showed no genotoxic potential at the doses investigated and thus could form the basis for a possible anticarcinogenic drug.

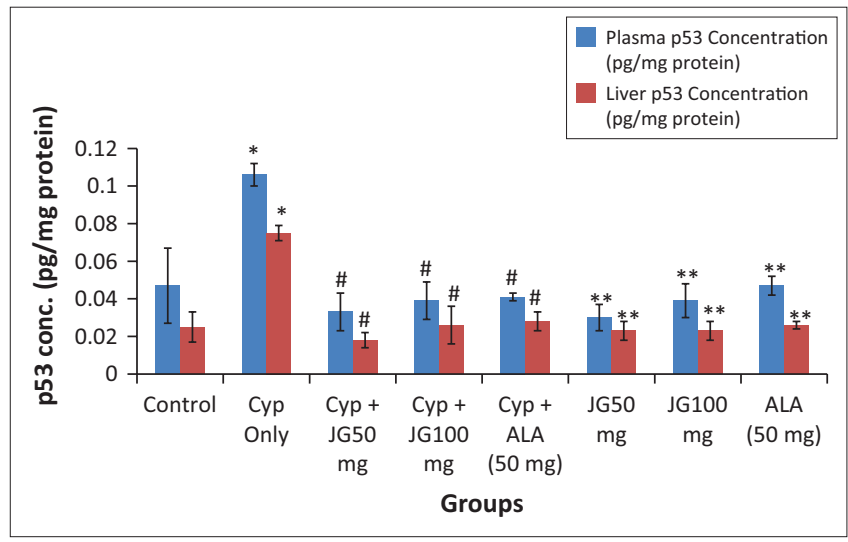

The bars represent mean $\pm \mathrm{SD}(n=7) ; *$, values are significant at $p<0.05$ when compared to control group; \#, values are significant at $p<0.05$ when compared to Cyp-only group; **, values are not significant at $p<0.05$ when compared to the control group.

ALA, alpha-lipoic acid; Cyp, cypermethrin.

FIGURE 2: Effect of crude methanolic leaves extract of Jatropha gossypifolia (J. gossypifolia $50 \mathrm{mg}$ and J. gossypifolia $100 \mathrm{mg}$ ) and alpha-lipoic acid on the p53 concentration of plasma and liver in rats pretreated with cypermethrin. 


\section{Acknowledgements}

\section{Competing interests}

The authors declare that they have no financial or personal relationships which may have inappropriately influenced them in writing this article.

\section{Authors' contributions}

O.O.F. designed and carried out the study and compiled the draft in the journal format. O.A.A. supervised the entire study, modified the study design, performed the result analysis and proofread the final draft of the article. R.N.U. helped with the result analysis and organisation. A.I.A. helped with the result analysis and interpretation as well as correction of the first draft of this article.

\section{References}

Ali, D., Nagpure, N.S., Kumar, S., Kumar, R. \& Kushwaha, B., 2008, 'Genotoxicity assessment of acute exposure of chlorpyriphos of fresh water fish Channa punctatus (Bloch) using micronucleus assay and alkaline single-cell gel electrophoresis', Chemosphere 71, 1823-1831. https://doi.org/10.1016/j.chemosphere.2008.02.007

Apurba, S.A., Faruq, H., Farhana, R., Shakhawat, H.B., Maima, M. \& Jamaluddin, A.T.M., 2013, 'Study of pharmacological activities of methanol extract of Jatropha gossypifolia fruits', Journal of Basic Clinical Pharmacy 4(1), 20-24. https://doi. org/10.4103/0976-0105.109404

Assayed, M.E., Khalaf, A.A. \& Salem, H.A., 2010, 'Protective effects of garlic extract and vitamin $C$ against in vivo cypermethrin-induced cytogenetic damage in rat bone-marrow', Mutation Research 702(1), 1-7. https://doi.org/10.1016/j. mrgentox.2010.02.020

Auudy, B., Ferreira, F., Blasina, L., Lafon, F., Arredondo, F., Dajas, R. et al., 2003, 'Screening of antioxidant activity of three Indian medicinal plants, traditionally used for the management of neurodegenerative diseases', Journal of Ethnopharmacology 84, 131-138. https://doi.org/10.1016/S0378-8741(02)00322-7

Balee, W., 1994, Footprints of the forest, $k a^{\prime}$ aporethnobotany - The historical ecology of plant utilization by an Amazonian people, Columbia University Press, New York p. 22.

Baur, A., Harrer, T. \& Peukert, M., 1991, 'Alpha-lipoic acid is an effective inhibitor of human immuno-deficiency virus (HIV-1) replication', Klin Wochenschur 69, 722-724. https://doi.org/10.1007/BF01649442

Bilska, A., Dudek, M., Iciek, M., Kwiecien, I., Sokolowska-Jezewicz, M., Filipek, B. et al., 2008 , 'Biological actions of lipoic acid associated with sulfane sulfur metabolism', Pharmacology Reports 60, 225-232.

Canadian Council on Animal Care, 1993, Guide to the care and use of experimental animals, vol. 2, CCAC, Ottawa, ON, Canada, pp. 2-21.

Chung, I., Cheon, W.H. \& Ku, S., 2011, 'Micronucleus test of picrorrhiza rhizoma aqueous extract in bone marrow cells of male ICR mice', Official Journal of Korea Society of Toxicology 27, 119-123. https://doi.org/10.5487/TR.2011.27.2.119

Cuthbertson, A.G.S. \& Murchie, A.K., 2010, 'Ecological benefits of Anystis baccarum in an orchard ecosystem and the need for its conservation', International Journal of Environmental Science and Technology 7, 807-881. https://doi.org/10.1007/ BF03326190

Ecobichon, D.J., 1996, 'Toxic effects of pesticides', in C.D. Klaasen (ed.), Casarett and Doull's toxicology: The basic science of poisons, 5th edn., pp. 643-690, McGraw Hill, New York.

Faokunla, O., Akinloye, O.A., Ugbaja, R.N. \& Adeogun, A.I., 2017, 'Phytochemical and nutritional status of Jatropha gossypifolia leaves', Imperial Journal of Interdisciplinary Research 3(4), 1877-1895.

Ganapathy, S. \& Shanmugam, M., 2010, Anti-clastogenic effect of berberine against DMBA-induced clastogenesis', Basic and Clinical Pharmacology and Toxicology 107, 818-824. https://doi.org/10.1111/j.1742-7843.2010.00579.x

Giri, S., Giri, A., Sharma, G.D. \& Prasad, S.B., 2003, 'Induction of sister chromatid exchanges by cypermethrin and carbosulfan in bone marrow cells of mice in vivo', Mutagenesis 18, 53-58. https://doi.org/10.1093/mutage/18.1.53

Gold, L.S., Slone, T.H., Ames, B.N. \& Manley, N.B., 2001, 'Pesticide residues in food and cancer risk: A critical analysis', in R.L. Krieger (ed.), Handbook of pesticide toxicology, 2nd edn., pp. 799-844, Academic Press, Cambridge, CA.

Grunert, R.R., 1960, 'The effect of DL-a-lipoic acid on heavy-metal intoxication in mice and dogs', Archives of Biochemistry and Biophysics 86, 190-194. https://doi. org/10.1016/0003-9861(60)90402-1

Hammam, F.M. \& El-Khatib, E.N., 2004, 'Trial for minimization the antifertility action and the genotoxicity of diazinon to male rats by using the different patterns of dipping', Egyptian Journal of Applied Sciences 19(2), 280-315.
Heddle, J.A., 1973, 'A rapid in vivo test for chromosome damage', Mutatation Research 18, 187-190. https://doi.org/10.1016/0027-5107(73)90035-3

Holmquist, L., Stuchbury, G. \& Berbaum, K., 2007, 'Lipoic acid as a novel treatment for Alzheimer's disease and related dementias', Pharmacology and Therapeutics 113 , 154-164. https://doi.org/10.1016/j.pharmthera.2006.07.001

Levine, A.J., 1997, 'p53, the cellular gatekeeper for growth and division', Cell 88 , 323-331. https://doi.org/10.1016/S0092-8674(00)81871-1

Matter, B. \& Schmid, W., 1971, 'Trenimon-induced chromosomal damage in bonemarrow cells of six mammalian species, evaluated by the micronucleus test' Mutation Research 12, 417-425. https://doi.org/10.1016/0027-5107(71)90092-3

Meinert, R., Schuz, J., Kaletsch, U., Kaatsch, P. \& Michaelis, J., 2000, 'Leukemia and non-Hodgkin's lymphoma in childhood and exposure to pesticides: Results of a register-based case-control study in Germany', American Journal of Epidemiology 151, 639-646. https://doi.org/10.1093/oxfordjournals.aje.a010256

Murugalakshmi, M., Mari, S.J., Vallimail, M., Anitha, P.R.J. \& Thangapandian, V., 2014 'Preliminary phytochemical analysis and antipyretic, purgative studies of Jatropha
gossypifolia', World Journal of Pharmacy and Pharmaceutical Sciences 3(7), gossypifolia',

Navayath, S. \& Thiyagarajan, D., 2013, Effect of aqueous extract of Trigonella foenum graecum in cypermethrin-induced genotoxicity, Nova Publishers, New York, p. 4.

Ojezele, M.O. \& Abatan, O.M., 2009, 'Toxicological effects of chloropyrifos and methidathion in young chickens', African Journal of Biochemistry Research 3, 48-51.

Okonko, L.E., Ikpeme, E.V. \& Udensi, O.U., 2016, 'Genotoxic effect of chlorpyrifos and cypermethrin in albino rats', Research Journal of Mutagenesis 6(1), 31-35. https://doi.org/10.3923/rjmutag.2016.31.35

Osweiler, G.D., 1996, Toxicology, William and Wilkins, Philadelphia, PA, pp. 1-2.

Packer, L., Kraemer, K. \& Rimbach, G., 2001, 'Molecular aspects of lipoic acid in the prevention of diabetes complications', Nutrition 17(10), 888-895. https://doi. org/10.1016/S0899-9007(01)00658-X

Packer, L., Witt, E.H. \& Tritschler, H.J., 1995, 'Alpha-lipoic acid as a biological antioxidant', Free Radical Biology and Medicine 19(2), 227-250. https://doi. org/10.1016/0891-5849(95)00017-R

Panda, B.B., Gaur, K., Kori, M.L., Tyagi, L.K., Nema, R.K. \& Sharma, C.S., 2009, 'Antiinflammatory and analgesic activity of Jatropha gossypifolia in experimental animal models', Global Journal of Pharmacology 3(1), 1-5.

Poletta, G.L., Larriera, A., Kleinsorge, E. \& Mudry, M.D., 2009, 'Genotoxicity of the herbicide formulation Roundup ${ }^{\circledast}$ (glyphosate) in broad-snouted caiman (Caiman latirostris) evidenced by the Comet assay and the Micronucleus test', Mutation Research/Genetic Toxicology and Environmental Mutagenesis 672, 95-102. https://doi.org/10.1016/j.mrgentox.2008.10.007

Raddatz, G. \& Bisswanger, H., 1997, 'Receptor site and stereospecificity of dihydrolipoamide dehydrogenase for R- and S-lipoamide: A molecular modeling study', Journal of Biotechnology 58(2), 89-100. https://doi.org/10.1016/S01681656(97)00135-1

Renner, H.W., 1990, 'In vivo effects of single or combined dietary antimutagens on mutagen-induced chromosomal aberrations', Mutation Research 244, 185-188. https://doi.org/10.1016/0165-7992(90)90070-Z

Rosenberg, H.R. \& Culik, R., 1959, 'Effect of a-lipoic acid on vitamin C and vitamin E deficiencies', Archives of Biochemistry and Biophysics 80, 86-93. https://doi org/10.1016/0003-9861(59)90345-5

Schalm, O.W., 1970, Veterinary hematology, 2nd edn., Lea and Febiger, Philadelphia, PA, p. 417.

Sehirli, O., Sener, E. \& Centinel, S., 2008, 'Alpha-lipoic acid protects against renal ischaemia-reperfusion injury in rats', Clinical and Experimental Pharmacology and Physiology 35, 249-255. https://doi.org/10.1111/j.1440-1681.2007.04810.x

Seth, R. \& Sarin, R., 2010, 'Analysis of the phytochemical content and anti-microbial activity of Jatropha gossypifolia L', Archives of Applied Science Research 2(5), 285-291.

Sheikh, M.S. \& Fornace, A.J., Jr., 2000, 'Role of p53 family members in apoptosis', Journal of Cellular Physiology 182, 171-181. https://doi.org/10.1002/(SICI)10974652(200002)182:2\%3C171::AID-JCP5\%3E3.0.CO;2-3

Singh, A., Ling, G., Suhasini, A.N., Zhang, P., Yamamoto, M., Navas-Acien, A. et al., 2009, 'Nrf2-dependent sulfiredoxin-1 expression protects against cigarette smoke-induced oxidative stress in lungs', Free Radical Biology and Medicine 46(3) 376-386. https://doi.org/10.1016/j.freeradbiomed.2008.10.026

Wenzel, U., Nickel, A. \& Daniel, H., 2005, 'Alpha-lipoic acid induces apoptosis in human colon cancer cells by increasing mitochondrial respiration with a concomitant $\mathrm{O}_{2}$-generation', Apoptosis 10, 359-368. https://doi.org/10.1007/ s10495-005-0810-x

Yekeen, A. \& Adeboye, K., 2013, 'Cytogenotoxic effects of cypermethrin, deltamethrin lambdacyhalothrin and endosulfan pesticides on Allium cepa root ceels' African Journal of Biotechnology 12(41), 6000-6006. https://doi.org/10.5897/ AJB2013.12802

Yerramsetty, N., Valluri, K., Shaik, R. \& Ramadoss, K., 2013, 'Antiinflammatory activity of leaves of Jatropha gossypifolia L. by HRBC membrane stabilization method', Journal of Acute Disease 2(2), 156-158. https://doi.org/10.1016/S2221 6189(13)60118-3

Ziegler, D., Ametov, A. \& Barinov, A., 2006, 'Oral treatment with a-lipoic acid improves symptomatic diabetic polyneuropathy', Diabetes Care 29(11), 2365-2370. https:// doi.org/10.2337/dc06-1216 